\title{
REGULATION OF NEOCORTICAL MUSCARINIC RECEPTORS: EFFECTS OF DRUG TREATMENT AND LESIONS ${ }^{1}$
}

\author{
MICHAEL MCKINNEY AND JOSEPH T. COYLE
}

Departments of Neuroscience, Pharmacology and Experimental Therapeutics, and Psychiatry and the Behavioral Sciences, Johns Hopkins University School of Medicine, Baltimore, Maryland 21205

Received March 19, 1981; Revised September 28, 1981; Accepted September 29, 1981

\begin{abstract}
The high affinity and low affinity muscarinic receptors of rat cerebral cortex were studied in various drug- and lesion-induced states by inhibiting the binding of $\left[{ }^{3} \mathrm{H}\right]$ quinuclidinyl benzilate (QNB) by carbamylcholine. Receptor density and affinity constants were determined by iterative computer fits of data to a noncooperative two-site competitive inhibition model. In control rat cortex, $\left[{ }^{3} \mathrm{H}\right] \mathrm{QNB}$ had an apparent $K_{D}$ of $76 \pm 7 \mathrm{pM}$ and a $B_{\max }$ of $229 \pm 9 \mathrm{pmol} / \mathrm{gm}$, wet weight tissue, while displacement of $\left[{ }^{3} \mathrm{H}\right] \mathrm{QNB}$ by carbamylcholine revealed a high affinity agonist site with a $K_{D}$ of $0.6 \pm 0.1 \mu \mathrm{M}$ and a low affinity agonist site with a $K_{D}$ of $66 \pm 5 \mu \mathrm{M}$. In whole cortex, $30 \pm 2 \%$ of the receptors were in the high affinity state. In the frontoparietal cortex, the concentration of agonist high affinity sites correlated with the density of innervation from the nucleus basalis of Meynert (nBM).

Chronic di-isopropyl fluorophosphate (DFP) treatment resulted in a $32 \pm 2 \%$ decrease in total sites due to a $47 \pm 4 \%$ decrease in the concentration of the low affinity site. Chronic atropine treatment increased total receptors by $49 \pm 5 \%$, due to a $107 \pm 19 \%$ increase in high affinity sites and a $25 \pm 9 \%$ increase in low affinity sites. Ablation of the $\mathrm{nBM}$ input by ibotenate $(18 \mu \mathrm{g})$ or electrothermic lesion resulted acutely (3 days post-lesion) in a $14 \pm 4 \%$ decrease in the low affinity sites and chronically ( $>3$ weeks) in a return of these sites to control levels and a $28 \pm 6 \%$ increase in high affinity sites over control levels. Prior lesion of the nBM did not fully protect against the downregulation of muscarinic sites in frontoparietal cortex produced by DFP treatment. The results of this study support the thesis that muscarinic receptors in the cerebral cortex are differentially regulatable by cholinergic input as well as by pharmacologic manipulations.
\end{abstract}

The potent muscarinic antagonist $\left[{ }^{3} \mathrm{H}\right]$ quinuclidinyl benzilate (QNB) binds in a monophasic manner to a single class of non-interacting muscarinic receptor sites in brain membranes (Yamamura and Snyder, 1974; Birdsall and Hulme, 1976; Hulme et al., 1978). However, agonist displacement of $\left[{ }^{3} \mathrm{H}\right] \mathrm{QNB}$ has revealed complex kinetics of inhibition compatible with multiple agonist binding sites (Birdsall and Hulme, 1976; Birdsall et al., 1978). There is biochemical evidence (Birdsall et al., 1979) supporting the theory that a single receptor protein

\footnotetext{
'We thank Dr. Mario Amzel for help in setting up the computer program and Carol Kenyon for excellent secretarial assistance. This research was supported by United States Public Health Service Grants DA-00266, MH-26654, and NS-13584, Research Scientist Development Award Type II KO MH-00125 to J. T. C., and a grant from the McKnight Foundation.

${ }^{2}$ To whom correspondence should be addressed at Department of Neuroscience, Johns Hopkins University School of Medicine, 725 North Wolfe Street, Baltimore, MD 21205.
}

exists, with its binding affinity altered by its coupling to another protein or by membrane characteristics. Birdsall and colleagues (1980) have argued further that, of the three classes of muscarinic agonist binding sites, the "low affinity" conformation is the functional (channel-coupled) site.

Recent studies, particularly in the hippocampal formation and in tissue culture systems, have shown that muscarinic receptors, as measured by the specific binding of $\left[{ }^{3} \mathrm{H}\right] \mathrm{QNB}$, are modulated by cholinergic input. Chronic blockade with antagonists causes an increase in receptor density (Ben-Barak and Dudai, 1980a; Simon and Klein, 1979), whereas chronic stimulation of the receptors by agonists causes a decrease in their number (Simon and Klein, 1979; Gazit et al., 1979). Potentiation of cholinergic input to the striatal muscarinic receptor by chronic inhibition of acetylcholinesterase causes decreases in $\left[{ }^{3} \mathrm{H}\right] \mathrm{QNB}$ binding sites and alterations in agonist binding (Ehlert et al., 1979). Currently, there is little information 
on the effects of these manipulations on the agonist conformations of the muscarinic receptor in the cerebral cortex.

In recent studies, we have demonstrated that a major portion of the cholinergic innervation to the frontoparietal cerebral cortex is derived from a group of multipolar neurons of the nucleus basalis of Meynert (nBM) in the ventral-medial globus pallidus (Johnston et al., $1979,1981 \mathrm{~b}$ ). Lesion of the nBM results in a 60 to $70 \%$ reduction in the presynaptic markers for cholinergic neurons and a complete loss of the radial acetylcholinesterase-stained axons in the frontoparietal cortex. Fetally induced lesions of the cerebral cortex as well as direct excitotoxin lesions of the neocortex suggest that up to $30 \%$ of the cholinergic innervation to rat neocortex is derived from intrinsic neurons; on the basis of laminar analysis, the intrinsic neurons appear to extend processes throughout all cortical layers (Johnston et al., 1981a). In the present study, we have examined the role of extrinsic cortical cholinergic innervation and cholinergic pharmacologic manipulations on the binding of antagonists and agonists to the muscarinic receptors in the neocortex.

\section{Materials and Methods}

Lesions and drug treatments. Adult male SpragueDawley rats weighing at least $180 \mathrm{gm}$ were used in all experiments. Lesions of the $\mathrm{nBM}$ in the ventral globus pallidus were performed with the aid of a David Kopf small animal stereotaxic apparatus at the following coordinates: $0.3 \mathrm{~mm}$ posterior to the bregma, $3.0 \mathrm{~mm}$ lateral to the midline, and $7.2 \mathrm{~mm}$ ventral to the pial surface. Electrothermic lesions were made with a Radionics RFG4 radiofrequency generator with the probe temperature maintained at $60^{\circ} \mathrm{C}$ for $1 \mathrm{~min}$; this resulted in destruction of brain tissue in a 1.5-mm-diameter sphere. Excitotoxin lesions were made by positioning a $0.3-\mathrm{mm}$ Hamilton cannula at these coordinates and infusing $1.0 \mu \mathrm{l}$ of isotonic buffer, $\mathrm{pH} 7.4$, containing $18 \mu \mathrm{g}$ of ibotenic acid (Regis Chemical Co., Milwaukee, WI).

For chronic atropine treatment, atropine sulfate monohydrate (Sigma Chemical Co., St. Louis, MO) at a dose of $40 \mathrm{mg} / \mathrm{kg}$ dissolved in distilled water was administered daily by intraperitoneal injection. For chronic di-isopropyl fluorophosphate (DFP; Sigma Chemical Co.) treatment, DFP was dissolved in distilled water and injected intramuscularly. On day 1 , a dose of $1 \mathrm{mg} / \mathrm{kg}$ was administered; on day 2 , a dose of $0.4 \mathrm{mg} / \mathrm{kg}$ was injected; and thereafter, daily doses of $0.2 \mathrm{mg} / \mathrm{kg}$ of DFP were given.

Tissue preparation. Most binding experiments were performed on crude homogenates of the frontoparietal cerebral cortex from which the cingulate and pyriform cortex had been dissected away. Tissue was frozen on dry ice until homogenization and stored up to 4 days at $-80^{\circ} \mathrm{C}$. The tissue was homogenized for $20 \mathrm{sec}$ at setting 6 with a Brinkmann Polytron at a dilution of 1:800 (w/v) in $50 \mathrm{~mm}$ sodium potassium phosphate buffer, $\mathrm{pH} 7.4$. For the survey of receptor density in subregions of the cerebral cortex, the dissection procedure described in Johnston et al. (1981a) was used. In some experiments, the effects of tissue storage, degree of homogenization, and extent of washing were examined. In other experiments, where receptor degradation in vitro and desensi- tization were examined, Krebs phosphate buffer was used.

Enzymatic assays. Enzyme assays were performed on portions of cortex homogenized in $50 \mathrm{~mm}$ Tris- $\mathrm{HCl}$ buffer, $\mathrm{pH} 7.4$, containing $0.2 \%(\mathrm{v} / \mathrm{v})$ Triton X-100. The activity of choline acetyltransferase was measured by the method of Bull and Oderfeld-Nowak (1971) and the activity of glutamate decarboxylase and acetylcholinesterase was measured by the methods of Wilson et al. (1972).

Receptor-ligand binding assay. Muscarinic receptors were characterized by the specific binding of $\mathrm{L}-\left[{ }^{3} \mathrm{H}\right]$ quinuclidinyl benzilate (QNB; $32 \mathrm{Ci} / \mathrm{mm}$; New England $\mathrm{Nu}$ clear Corp.). Typically, a $0.2-\mathrm{ml}$ suspension of cortical tissue $(1: 800)$ was incubated in a total volume of $2 \mathrm{ml}$ of $50 \mathrm{~mm}$ phosphate buffer containing the appropriate drugs and with a final concentration of $\left[{ }^{3} \mathrm{H}\right] \mathrm{QNB}$ of 1.5 to 1.8 nM. Under these conditions, greater than $98 \%$ of the ${ }^{3} \mathrm{H}$ ligand remained free in solution. Nonspecific binding was determined in the presence of $10 \mu \mathrm{M}$ atropine or $100 \mu \mathrm{M}$ oxotremorine (Sigma Chemical Co.). Each experimental point was the average of triplicate assays of the total binding of $\left[{ }^{3} \mathrm{H}\right] \mathrm{QNB}$.

Incubations were carried out at $25^{\circ} \mathrm{C}$ for $75 \mathrm{~min}$, but, in some experiments, homogenates were incubated at $4^{\circ} \mathrm{C}$ for $90 \mathrm{~min}$. For agonist displacement curves, carbamylcholine (carbachol; Sigma Chemical Co.) was added in varying concentrations prior to the addition of the $\left[{ }^{3} \mathrm{H}\right] \mathrm{QNB}$. At the end of the incubation, the membranes were isolated on Whatman GF/B fiberglass filters with a manifold filtration apparatus; filters were washed rapidly four times with $4 \mathrm{ml}$ of ice cold $50 \mathrm{~mm}$ sodium phosphate buffer. Radioactivity bound to the filter was solubilized by shaking for $2 \mathrm{hr}$ at room temperature in $12.5 \mathrm{ml}$ of Formula 947 (New England Nuclear Corp., Boston, MA). Radioactivity was measured in a Searle Scintillation Spectrometer with a counting efficiency of $43 \%$. In the case of saturation isotherms for $\left[{ }^{3} \mathrm{H}\right] \mathrm{QNB}$, concentrations of free $\left[{ }^{3} \mathrm{H}\right] \mathrm{QNB}$ were calculated by subtracting the amount bound from the total amount of ${ }^{3} \mathrm{H}$ ligand in the assay mixture.

Data analysis. $\left[{ }^{3} \mathrm{H}\right] \mathrm{QNB}$ was found to bind to the total muscarinic receptor population with a single equilibrium affinity constant under the concentration range used in the present studies. The agonists were found to displace specifically bound $\left[{ }^{3} \mathrm{H}\right] \mathrm{QNB}$ completely. For analysis of this displacement, competitive antagonist-agonist interaction and two-site noncooperative agonist occupancy was assumed. Thus, the "high affinity" site measured in these experiments reflects the combination of the more prevalent high affinity site and the less prevalent "super" high affinity site (Birdsall et al., 1978). The following equilibrium equations hold in the competitive assay:

$$
\begin{gathered}
Q+R=Q R \\
A+R_{H}=A R_{H} \\
A+R_{L}=A R_{L}
\end{gathered}
$$

where $Q$ is the $\left[{ }^{3} \mathrm{H}\right] \mathrm{QNB} ; A$ represents the agonist; $R$ represents all three muscarinic receptors; $R_{H}$ and $R_{L}$ are, respectively, the high and low affinity muscarinic receptors; and $Q R, A R_{H}$ and $A R_{L}$ represent $\left[{ }^{3} \mathrm{H}\right] \mathrm{QNB}$ receptor and agonist-receptor complexes. In saturation studies 
with $\left[{ }^{3} \mathrm{H}\right] \mathrm{QNB}$ without a competitor present, the amount of specific ligand -receptor complex is given by:

$$
(Q R)=\frac{K_{Q}(Q)\left(B_{\max }\right)}{1+K_{Q}(Q)}
$$

where $(Q)$ is the free concentration of $\left[{ }^{3} \mathrm{H}\right] \mathrm{QNB},(Q R)$ is the amount of $\left[{ }^{3} \mathrm{H}\right] \mathrm{QNB}$ specifically bound to the muscarinic receptor, $K_{Q}$ is the affinity constant of the receptor for $\left[{ }^{3} \mathrm{H}\right] \mathrm{QNB}$, and $B_{\max }$ is the total receptor concentration expressed as femtomoles of sites per $\mathrm{mg}$ of tissue, wet weight. $Q$ is expressed as the nanomolar concentration of $\left[{ }^{3} \mathrm{H}\right] \mathrm{QNB}$ and $K_{Q}$ is expressed as $\mathrm{nM}^{-1}$. In saturation studies, the concentration of $\left[{ }^{3} \mathrm{H}\right] \mathrm{QNB}$ varied from 0.03 to $2.0 \mathrm{nM}$.

For competitive displacement of $\left[{ }^{3} \mathrm{H}\right] \mathrm{QNB}$ by an unlabeled agonist, which has different affinities for the two non-interacting sites, and when the free ligand concentrations are essentially equal to total ligand concentrations during the binding assay, the following holds:

$$
(Q R)=\frac{K_{Q}(Q)\left(B_{H}\right)}{1+K_{Q}(Q)+K_{H}(A)}+\frac{K_{Q}(Q)\left(B_{L}\right)}{1+K_{Q}(Q)+K_{L}(A)}
$$

where $B_{H}$ is the concentration of agonist high affinity sites, $B_{L}$ is the concentration of agonist low affinity sites, and $K_{H}$ and $K_{L}$ are the affinity constants of the two receptor subtypes for the agonist. Equation 5 can be simplified to:

$$
(Q R)=F_{H}\left(B_{H}\right)+F_{L}\left(B_{L}\right)
$$

where $F_{H}$ and $F_{L}$ represent the fractions of occupancy by $\left[{ }^{3} \mathrm{H}\right] \mathrm{QNB}$ of the high and low affinity agonist receptors, respectively. With the parameters $(A),(Q), K_{Q}, K_{H}$, and $K_{L}$ known and $(Q R)$ and $B_{\max }\left(B_{M}\right)$ measured, then $F_{H}$ and $F_{L}$ can be calculated, and the equation can be solved for $B_{H}$ and $B_{L}$.

For data analysis, an iterative, nonlinear curve-fitting Fortran program (Fletcher and Shrager, 1973) from the National Institutes of Health (courtesy of J. E. Fletcher) containing the code for a Gauss-Newton fitting algorithm using the Marquardt-Levenberg method of approach to the least sum of squared residual errors was used in a Digital Dec 10 computer. The model to which data were fit was that of equation 5 and data input comprised 15 pairs of values of $(A)$ and $(Q R)$. The parameters of $(Q)$ and $K_{Q}$ were measured independently in each experiment and served as constants in the model. The program generated values for $\left(B_{H}\right),\left(B_{L}\right), K_{H}$, and $K_{L}$. For most of the analysis, a single constraint (requiring non-negative values of the four parameters) was imposed on the iterative fit and usually less than 15 iterations were required to achieve a fit. The criterion for optimum fit was the minimum sum of squared residuals. When an iteration (which involved changes in one or more of the parameters in the direction to improve the fit) did not improve this minimum, the fit of the data to the model was considered complete. Each set of data was plotted along with the theoretical curves to examine visually the goodness of fit. Additionally, the goodness of fit was examined statistically (see below).

The affinities of the agonist binding sites probably do not vary with brain region (Birdsall et al., 1980), and fixed (control) values of $K_{H}$ and $K_{L}$ were used in the regional survey (Fig. 1). Physiological or pharmacological manipulations may, however, induce changes in agonist binding site affinities as well as capacities. Therefore, in the analysis of receptor binding data after such manipulations, all four parameters were allowed to converge unconstrained (except to have non-negative values) upon the best value. The affinities and capacities are, nevertheless, highly correlated in the model. With small changes in the parameters, it may not be clear whether affinities or capacities, or both, actually alter. In one such case (the chronic denervation data of Table III), an unconstrained model was compared to one in which $K_{H}$ and $K_{L}$ were constrained to control values. The sum of squared residuals increased 2- to 10 -fold (average about 4-fold, $N=6$ ) by the addition of constraints. Thus, it was considered appropriate to allow all of the model parameter values to vary when fitting data.

In each experiment, muscarinic receptor binding characteristics $\left(K_{Q}, K_{H}, K_{L}, B_{H}\right.$, and $\left.B_{L}\right)$ were determined by the dual assay of $\left[{ }^{3} \mathrm{H}\right] \mathrm{QNB}$-agonist competition and $\left[{ }^{3} \mathrm{H}\right] \mathrm{QNB}$ saturation binding isotherms performed on the same tissue homogenate. The values given are those determined from the computer program and from Scatchard plots of the $\left[{ }^{3} \mathrm{H}\right] \mathrm{QNB}$ saturation isotherms. Use was made of equation 6 in an "abbreviated assay" where $(Q)$ was fixed at $1.75 \mathrm{nM}$ and $(A)$ was fixed at $32 \mu \mathrm{M}$ of carbamylcholine.

With an initial examination of the $\left[{ }^{3} \mathrm{H}\right] \mathrm{QNB}$-carbachol competition curves for eight combined control animals, the data points in these curves were averaged and weighted according to the inverse of the standard error of the mean. The data then were fitted by both a twosite model (equation 5) and a three-site model for which terms for the binding to a "super high" affinity site of affinity $K_{S H}$ and capacity $B_{S H}$ were added. The addition of two parameters to the model did indeed improve the fit. The sum of squared residuals decreased from 725 for two sites to 336 for three sites, and root-mean-squared error decreased from 8.1 (two sites) to 6.1 (three sites). The three-site model gave a "super high" affinity binding site of $10.2 \%$ of total sites, similar to that reported by Birdsall et al. (1980), and a $K_{D}$ of $2.2 \mathrm{nM}$ for carbachol. However, because of the low proportion of these sites, the limited number of data points (three) in the region of the inflection point for the displacement curve for these "super high" affinity sites, and the standard errors involved, changes induced in these sites could not be determined reliably from our experiments.

For statistical comparisons, the values derived from an individual saturation isotherm or carbachol displacement curve were considered single experimental points. Means and standard errors were derived from groups of values obtained from separate experimental preparations. The Student's $t$ test was used to assess levels of significance. In the studies comparing the differential down-regulation of the receptor (lesioned side versus non-lesioned side), the paired $t$ test was used. In the initial evaluation of the fitting program to control data, the goodness of fit to two-site and three-site models was examined by comparing the sum of squared residuals. The data were examined further for systematic deviations from the models by the analysis of residuals by the method described by Hulme 
et al. (1978). This involves the calculation of a "nearest neighbor residual correlation coefficient" for pairs of residual values in order of increasing ligand concentrations. The coefficient then can be used to calculate a $t$ statistic to determine if the data fit contains systematic deviations. For control data fitted to a two-site model, $t$ $=0.868 ; N=13$; for the same data fitted to a three-site model, $t=1.2 ; N=13$. Neither $t$ value was significant, indicating no systematic deviations present for fit to either model. For the reasons mentioned above, the twosite model without constraints was used for all data analysis. Systematic deviations were not examined further, but periodically the convergence of the model was tested by varying the "starting values" of the parameters and by monitoring the value of the "condition" of each parameter. This is a number derived from the matrix calculations in the fitting algorithm, and its value exceeding the parameter value by several orders of magnitude is an indication of highly correlated data or a model with too many parameters for the number of data points. For the two-site model (of which two of the six parameters are predetermined constants), the "condition" always remained well within acceptable limits.

\section{Results}

Distribution of muscarinic receptors in subareas of cerebral cortex. The distribution of muscarinic receptors and the relative percentage in the high affinity agonist binding sites were determined in 24 subareas of the cerebral cortex with the "abbreviated assay technique." Specific binding of $\left[{ }^{3} \mathrm{H}\right] \mathrm{QNB}$ was measured at $25^{\circ} \mathrm{C}$ with $0.25 \mathrm{mg}$ of tissue homogenate in the presence or absence of $32 \mu \mathrm{M}$ carbachol. This concentration of carbachol occludes $70 \%$ of the high affinity agonist sites but only $6 \%$ of the low affinity agonist sites. The relative percentage of the receptors in the high affinity and low affinity conformation was estimated as described under "Materials and Methods" using the control values of $K_{H}$ and $K_{L}$ shown in Table $I$. Total muscarinic receptor density varied only $20 \%$ from the highest to the lowest subregion, with the somatosensory areas having somewhat higher levels and the caudal cingulate cortex having somewhat lower levels than the mean. Whereas the number of low affinity agonist sites appeared to be relatively evenly distributed throughout the cortex, the number of high affinity sites varied over 2 -fold from the highest to the lowest subareas (Fig. 1).

There was no significant correlation between the density of cortical muscarinic receptors and the specific activity of choline acetyltransferase among the 24 regions $(r=-0.046)$. Accordingly, the relationship between muscarinic receptor characteristics and cortical innervation from the basal globus pallidus was examined. The relative contribution of the $\mathrm{nBM}$ projection to the total complement of cortical cholinergic innervation in motor and somatosensory areas was determined by the absolute reduction in the specific activity of choline acetyltransferase 1 week following electrothermic lesion of the basal

TABLE I

Effects of chronic treatment with DFP on cortical muscarinic receptors Rats were treated with DFP for at least 5 days, and membranes from the frontoparietal cortex were assayed for the specific binding of $\left[{ }^{3} \mathrm{H}\right] \mathrm{QNB}$ and carbachol displacement of $\left[{ }^{3} \mathrm{H}\right] \mathrm{QNB}$ at $25^{\circ} \mathrm{C}$. The results are the means ( $\pm \mathrm{SEM}$ ) of the computer-generated values for the number of preparations indicated in parentheses.

\begin{tabular}{lcc}
\hline & Control (9) & Chronic DFP (7) \\
\hline$K_{Q}(\mathrm{nM})$ & $0.08 \pm 0.02$ & $0.07 \pm 0.01$ \\
$K_{H}(\mu \mathrm{M})$ & $0.6 \pm 0.1$ & $1.3 \pm 1.1$ \\
$K_{L}(\mu \mathrm{M})$ & $65 \pm 5$ & $216 \pm 34^{a}$ \\
$B_{H}(\mathrm{pmol} / \mathrm{mg}$ tissue $)$ & $69 \pm 6$ & $72 \pm 5$ \\
$B_{L}(\mathrm{pmol} / \mathrm{mg}$ tissue $)$ & $160 \pm 8$ & $84 \pm 7^{b}$ \\
$B_{M}(\mathrm{pmol} / \mathrm{mg}$ tissue $)$ & $229 \pm 9$ & $156 \pm 5^{b}$ \\
$B_{H}(\%)$ & $30 \pm 3$ & $46 \pm 3^{b}$ \\
\hline
\end{tabular}

${ }^{a} p<0.05$ versus control.

${ }^{b} p<0.001$ versus control.

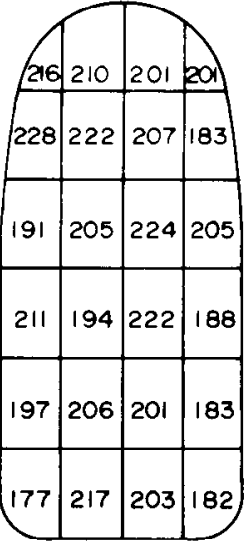

$\mathrm{B}_{\mathrm{M}}$

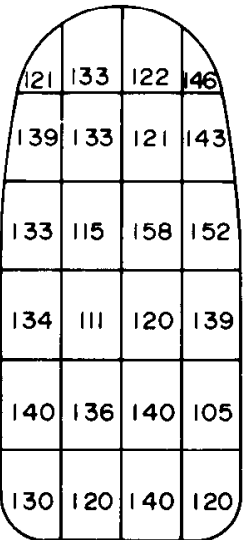

$B_{L}$

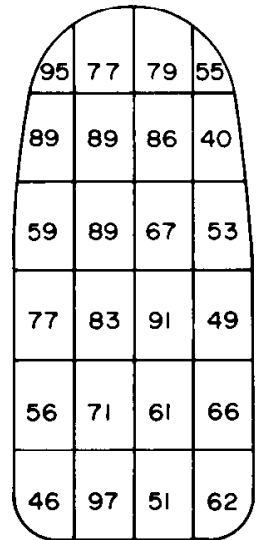

$\mathrm{B}_{\mathrm{H}}$

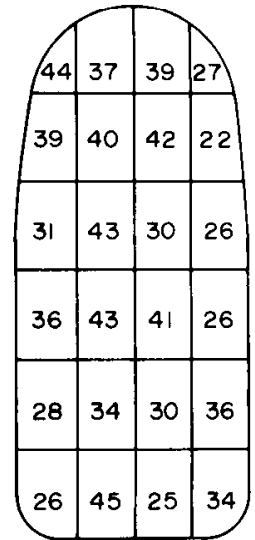

$\% \mathrm{~B}_{\mathrm{H}}$

Figure 1. Distribution of muscarinic receptors in subareas of the cerebral cortex. The neocortex above the rhinal fissure was subdivided into 24 blocks and assayed for the total specific binding of $\left[{ }^{3} \mathrm{H}\right] \mathrm{QNB}$ and the agonist high and low affinity sites with the "abbreviated assay" described under "Materials and Methods." The frontal pole is superior and the cingulate is on the right. The results are the mean of three preparations, each assayed in triplicate, and are expressed in femtomoles per $\mathrm{mg}$ with $\mathrm{SE}<10 \%$ of the mean. 
pallidus. As Figure 2 indicates, there is a significant correlation between the absolute reduction in choline acetyltransferase activity after the peripallidal lesion and the number of high affinity agonist sites in comparable cortical subregions in unlesioned rats $(r=0.72 ; N=18$; $p<0.001$ ). Since the major source of variation in the total number of muscarinic receptors results primarily from differences in the number of high affinity agonist sites, a correlation between the total number of muscarinic receptors and $\mathrm{nBM}$ input to the cerebral cortex also was obtained $(r=0.75 ; N=18 ; p<0.001)$.

Effects of chronic drug treatment on cortical muscarinic receptors. Rats were treated chronically with DFP, as described under "Materials and Methods," to inhibit acetylcholinesterase and thereby potentiate cholinergic neurotransmission. In the DFP-treated rats, acetylcholinesterase activity in the cerebral cortex was decreased by $90 \pm 2 \%(N=6)$. Treatment for 5 weeks resulted in a $33 \%$ reduction in the number of muscarinic receptor sites in the cortex with no apparent change in the affinity of $\left[{ }^{3} \mathrm{H}\right] \mathrm{QNB}$ for the receptor (Fig. $3 A$ ). The carbachol displacement curve (Fig. $3 B$ ) revealed that the reduction in sites reflected exclusively a $50 \%$ decrease in the number of low affinity agonist sites, whereas the high affinity agonist sites were not affected significantly (Table I). The time course of this down-regulation was followed out to 35 days and found to be stable; the effect was complete after about 4 days of treatment $(-34 \pm 3 \% ; N$ $=5$ ).

The effects of chronic treatment with the muscarinic antagonist, atropine, then were examined. In preliminary experiments, the ability of the tissue washes to eliminate contaminating atropine, which could affect the kinetics of binding, was examined. Atropine was added to cortical homogenates to a final concentration of $1 \mu \mathrm{M}$; "spiked" and control homogenates were carried through the same washing procedure and assayed for agonist and antagonist binding parameters; $K_{Q}(0.09 \mathrm{nM})$ and the percentage of $B_{H}(35 \%)$ measured in the "spiked" homogenates were comparable to the unspiked controls. While these results

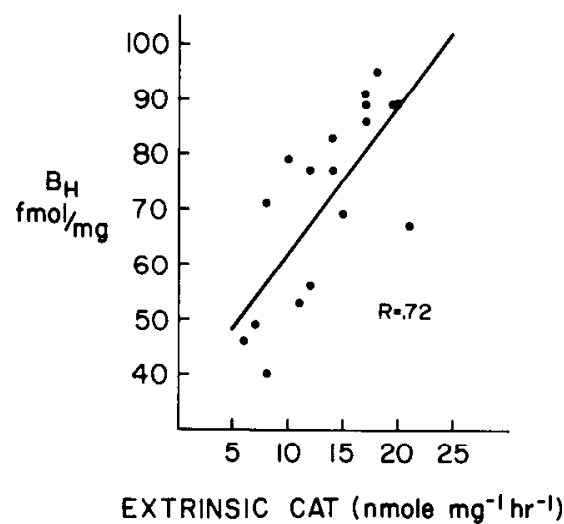

Figure 2. Relationship between the density of muscarinic agonist high affinity sites and cholinergic innervation from the basal forebrain in subareas of the frontoparietal cortex. The density of the agonist high affinity site $\left(B_{H}\right)$ was correlated with the absolute reduction of the specific activity of choline acetyltransferase $(C A T)$ in comparable subareas following lesion of the nBM. $N=18 ; r=0.72 ; p<0.001$.
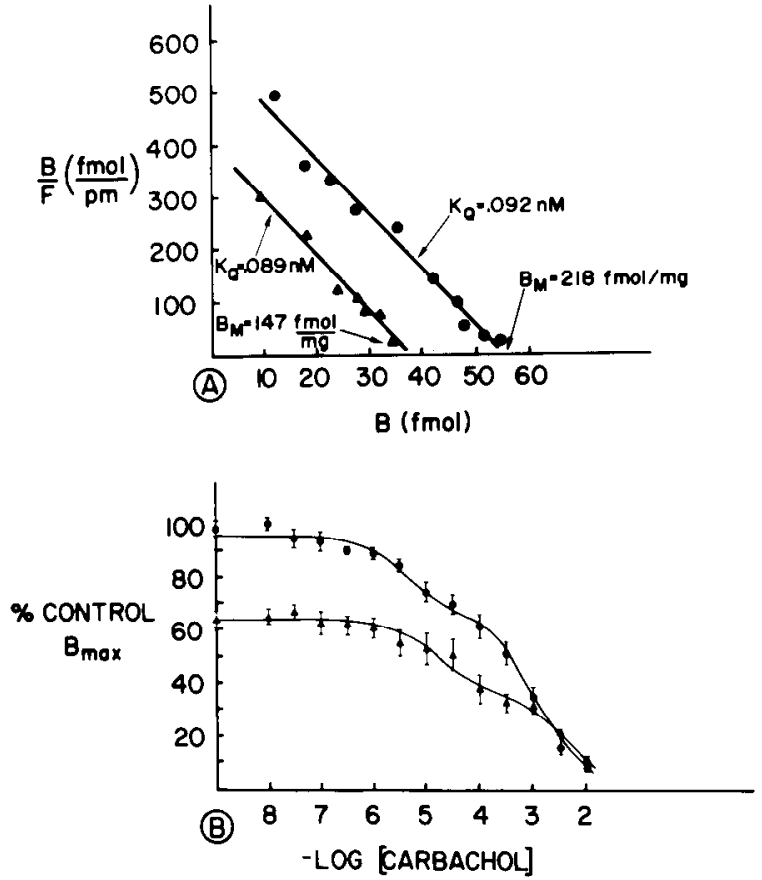

Figure 3. Effects of chronic treatment with DFP on cortical muscarinic receptors. Rats were treated with DFP as described under "Materials and Methods" for 5 weeks. $A$, Scatchard transformation of saturation isotherms for the specific binding of $\left[{ }^{3} \mathrm{H}\right] \mathrm{QNB}$ in control $(O)$ and DFP-treated $(\Delta)$ rats. Each point is the mean of four preparations assayed in triplicate. $B$, Carbachol displacement curves of the specific binding of $\left[{ }^{3} \mathrm{H}\right] \mathrm{QNB}(1.75 \mathrm{nM})$ in cortex from control $(O)$ and DFP-treated (A) rats. Each point is the mean of eight (control) and four (DFP) preparations assayed in triplicate with the SEM indicated by the bars. Computer-generated kinetic values using these averaged points are similar to the results listed in Table I (which are averages of more data, covering several time points).

indicate that contaminating atropine can be removed effectively by the washes, the extensive manipulation of the homogenates resulted in a significant $30 \%$ loss in the number of receptor sites. Accordingly, control samples were processed identically with the samples from atropine-treated rats to correct for receptor loss, and data are expressed relative to recovered protein. Rats treated for at least 5 weeks with atropine $(40 \mathrm{mg} / \mathrm{kg} /$ day $)$ exhibited a $48 \%$ increase in the total number of muscarinic receptor sites in the neocortex (Table II). Calculation of the number of receptor subtypes indicated a 2 -fold increase in high affinity agonist sites and a $25 \%$ increase in low affinity agonist sites.

Effects of acute denervation on cortical muscarinic receptors. Because of pharmacologic evidence for the existence of muscarinic autoreceptors (Szerb, 1978), it was important to determine the possible contribution of autoreceptors on cholinergic terminals to the total number of cortical muscarinic receptors. The $\mathrm{nBM}$ was ablated by stereotaxic injection of $18 \mu \mathrm{g}$ of ibotenic acid $(N=5)$, and the animals were sacrificed by $72 \mathrm{hr}$ after lesion for analysis. The lesion caused a $66 \%$ decrease in the specific activity of choline acetyltransferase in the ipsilateral frontal parietal cortex with no significant decrement in the specific activity of glutamic acid decarbox- 
ylase, a marker for cortical intrinsic GABAergic neurons (Table III). The acute lesion resulted in a significant ( $p$ $<0.05)$ 13\% decrease in the total number of QNB binding sites with no alteration in the apparent $K_{D}$ for $\left[{ }^{3} \mathrm{H}\right] \mathrm{QNB}$. Carbachol agonist displacement curves (Fig. 4) indicated that the loss in receptor sites reflected a $14 \%$ decrement in the number of low affinity sites (Table III). These results are compatible with a partial localization of low affinity agonist receptors on cortical cholinergic terminals arising from the $\mathrm{nBM}$.

Effects of chronic denervation on cortical muscarinic receptor. The effects of prolonged cortical cholinergic denervation were examined at 5 weeks after ibotenate lesion of the nBM. These lesions resulted in a 58\% reduction in the specific activity of choline acetyltransferase in the frontoparietal cortex ipsilateral to the lesion (Table III). The number of binding sites for $\left[{ }^{3} \mathrm{H}\right] \mathrm{QNB}$

\section{TABLE II}

Effects of chronic atropine treatment on cortical muscarinic receptors Rats were treated with atropine $(40 \mathrm{mg} / \mathrm{kg})$ for at least 5 days; membranes prepared from the frontoparietal cortex were washed extensively to eliminate contaminating atropine. The specific binding of $\left[{ }^{3} \mathrm{H}\right] \mathrm{QNB}$ and carbachol displacement were performed at $25^{\circ} \mathrm{C}$, and the protein content of the membrane preparations was measured. The results are the means $( \pm \mathrm{SEM})$ of the computer-generated values for the number of preparations indicated in parentheses.

\begin{tabular}{lcc}
\hline & Recovery Control (3) & Atropine-treated (6) \\
\hline$K_{Q}(\mathrm{nM})$ & $0.08 \pm 0.01$ & $0.08 \pm 0.01$ \\
$K_{H}(\mu \mathrm{M})$ & $0.6 \pm 0.1$ & $1.5 \pm 0.6$ \\
$K_{L}(\mu \mathrm{M})$ & $66 \pm 5$ & $92 \pm 23$ \\
$B_{H}(\mathrm{pmol} /$ mg protein) & $552 \pm 30$ & $1146 \pm 106^{a}$ \\
$B_{L}$ (pmol/mg protein) & $1345 \pm 19$ & $1678 \pm 117^{b}$ \\
$B_{M}(\mathrm{pmol} / \mathrm{mg}$ protein) & $1897 \pm 13$ & $2823 \pm 103^{a}$ \\
$B_{H}(\%)$ & $29 \pm 1$ & $41 \pm 3^{a}$ \\
\hline
\end{tabular}

${ }^{a} p<0.001$ versus recovery controls.

${ }^{b} p<0.05$ versus recovery controls.

TABLE III

Effects of nucleus basalis lesions on cortical muscarinic receptors

The peripallidal neuronal perikarya in the nucleus basalis were lesioned by stereotaxic injection of $18 \mu \mathrm{g}$ of ibotenate. The rats were killed within 3 days ("acute") or 5 weeks ("chronic") after injection, and the frontoparietal cortex was dissected away. The activities of choline acetyltransferase and glutamate decarboxylase were measured in a wedge from the sample. The membranes prepared from the samples were assayed for the specific binding of $\left[{ }^{3} \mathrm{H}\right] \mathrm{QNB}$ and carbachol displacement of $\left[{ }^{3} \mathrm{H}\right] \mathrm{QNB}$ at $25^{\circ} \mathrm{C}$. The results are the means $( \pm \mathrm{SEM})$ of the computer-generated values for the number of preparations indicated in parentheses.

\begin{tabular}{lccc}
\hline & Control (9) & Acute (5) & Chronic (6) \\
\hline$K_{Q}(\mathrm{pM})$ & $76 \pm 7$ & $103 \pm 14$ & $109 \pm 12$ \\
$K_{H}(\mu \mathrm{M})$ & $0.6 \pm 0.1$ & $0.8 \pm 0.2$ & $1.0 \pm 0.4$ \\
$K_{L}(\mu \mathrm{M})$ & $66 \pm 5$ & $68 \pm 14$ & $178 \pm 37^{a}$ \\
$B_{H}(\mathrm{pmol} / \mathrm{mg}$ tissue) & $69 \pm 5.6$ & $54 \pm 14$ & $88 \pm 4^{a, b}$ \\
$B_{L}(\mathrm{pmol} / \mathrm{mg}$ tissue) & $159 \pm 8$ & $137 \pm 7^{a}$ & $145 \pm 7$ \\
$B_{M}(\mathrm{pmol} / \mathrm{mg}$ tissue) & $228 \pm 9$ & $191 \pm 2^{a}$ & $233 \pm 6^{b}$ \\
$B_{H}(\%)$ & $30 \pm 2$ & $31 \pm 6$ & $38 \pm 2^{a}$ \\
$\begin{array}{l}\text { Choline acetyltrans- } \\
\quad \text { ferase (\%) }\end{array}$ & $100 \pm 6$ & $34 \pm 4$ & $42 \pm 6$ \\
$\begin{array}{l}\text { Glutamate decarbox- } \\
\quad \text { ylase (\%) }\end{array}$ & $100 \pm 6$ & $104 \pm 3$ & $104 \pm 6$ \\
\hline
\end{tabular}

" $p<0.05$ versus control.

${ }^{b} p<0.05$ versus acute.

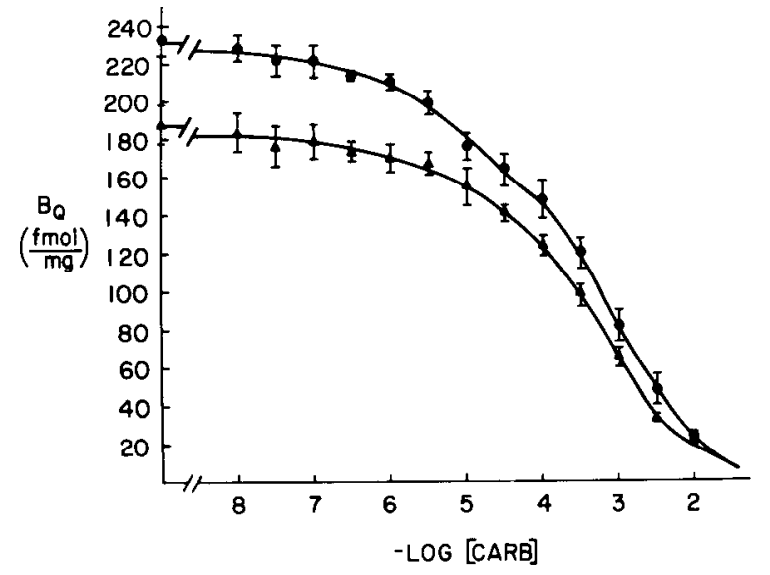

Figure 4. Effects of acute lesion of $\mathrm{nBM}$ on the carbachol $(C A R B)$ displacement of $\left[{ }^{3} \mathrm{H}\right] \mathrm{QNB}$ in cortex. Rats received ibotenate lesions of the $\mathrm{nBM}$ within 3 days of sacrifice. The displacement of $\left[{ }^{3} \mathrm{H}\right] \mathrm{QNB}(1.75 \mathrm{nM})$ by carbachol was examined in homogenates of the frontoparietal cortex of control (O) or lesioned (A) rats. Each point is the mean $( \pm \mathrm{SEM})$ of at least five preparations assayed in triplicate. Computer-generated kinetic values are listed in Table III.

and their affinity did not differ significantly from that of control, whereas receptor number was elevated in comparison to the level observed with the acute lesion. The carbachol agonist displacement curves revealed a significant $28 \%$ increase ( $63 \%$ compared to acute) in the number of high affinity sites with no alteration in the number of low affinity sites.

It seemed possible that agonist receptor states might be converted by a temperature-dependent process during incubation at $25^{\circ} \mathrm{C}$, which would obscure the magnitude of alteration in agonist high affinity sites caused by denervation. Accordingly, we examined the effects of the chronic $\mathrm{nBM}$ lesion on agonist and antagonist binding under conditions in which both tissue preparation and incubation were carried out at $4^{\circ} \mathrm{C}$ to reduce possible temperature-dependent receptor interconversion. The $K_{D}$ for $\left[{ }^{3} \mathrm{H}\right] \mathrm{QNB}$ is 12 -fold greater at $4^{\circ} \mathrm{C}$ than at $25^{\circ} \mathrm{C}$ and equilibrium was not achieved during the 90-min incubation (Fig. 5A). However, the percentage of receptors in the high affinity agonist conformation did not differ significantly in cortical tissue under the two incubation conditions (Fig. $5 B$ ). Comparison of $\left[{ }^{3} \mathrm{H}\right] \mathrm{QNB}$ binding and carbachol displacement at $4^{\circ} \mathrm{C}$ in frontoparietal cortex ipsilateral and contralateral to an ibotenate lesion of the $\mathrm{nBM}$ placed 5 weeks prior to sacrifice revealed an increase in total $\left[{ }^{3} \mathrm{H}\right] \mathrm{QNB}$-labeled sites with a significant $54 \%$ increase in the high affinity agonist sites on the lesioned side (Table IV). Thus, incubation conditions did not affect agonist conformation of the receptors after denervation, and denervation increased $B_{H}$ exclusively.

Effects of DFP treatment in basalis-lesioned rats on cortical muscarinic receptors. Although the chronic lesion of the $\mathrm{nBM}$ resulted in a significant increase in the number of the cortical high affinity agonist sites, the increment was only one-third of that noted in the rats treated chronically with atropine. This disparity suggested that the nBM cortical cholinergic projection plays 
only a limited role in regulating cortical muscarinic receptors; i.e., more receptors may be devoted to the intrinsic cholinergic system than to the subcortical projection. To clarify further the contribution of the subcortical

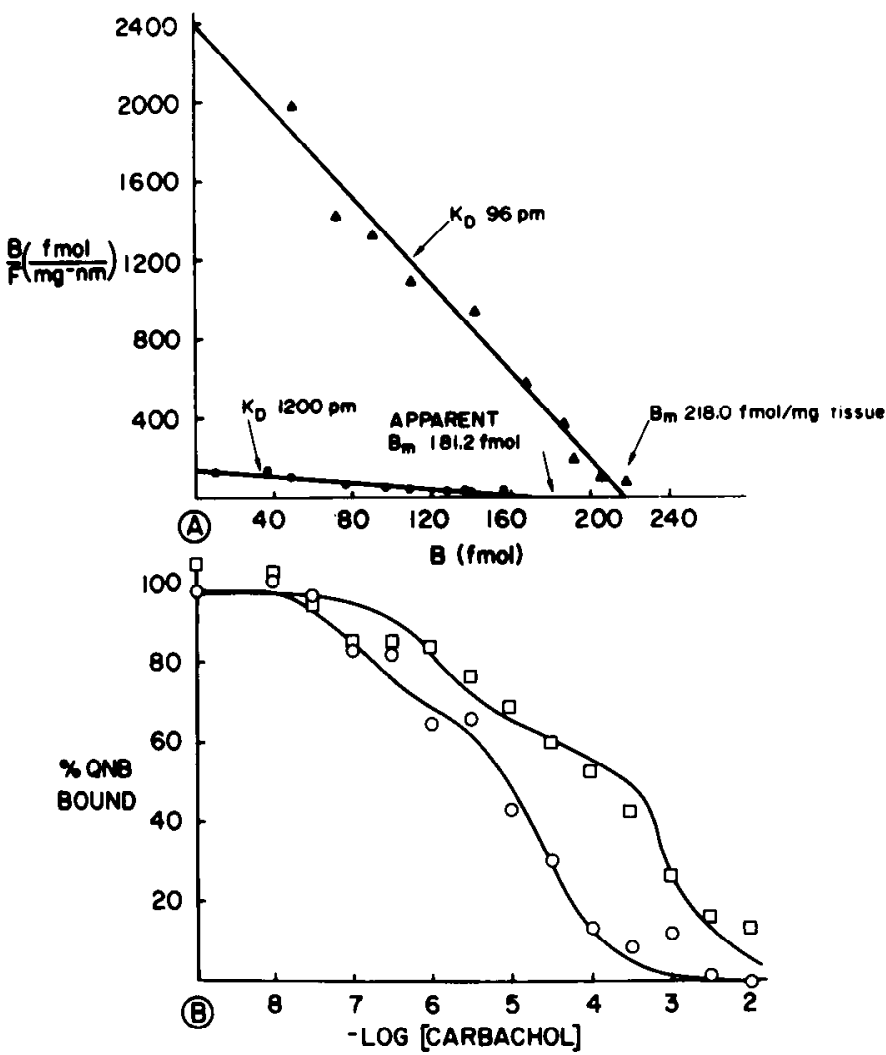

Figure 5. Effects of temperature on the kinetics of ligand binding to cortical muscarinic receptors. $A$, Scatchard transformation of the saturation isotherm for the specific binding of $\left[{ }^{3} \mathrm{H}\right] \mathrm{QNB}$ to cortical homogenates incubated at $25^{\circ} \mathrm{C}(\boldsymbol{\Delta})$ and $4^{\circ} \mathrm{C}$ (O). $B$, Carbachol displacement curve of the specific binding of $\left[{ }^{3} \mathrm{H}\right]$ QNB $(1.75 \mathrm{nM})$ performed at $4^{\circ} \mathrm{C}(\mathrm{O})$ and at $25^{\circ} \mathrm{C}$ (口). Each point is the mean of triplicate determinations. Computer-generated kinetic values indicate that $69 \%$ of the receptors were $B_{L}$ at $4^{\circ} \mathrm{C}$ and that $64 \%$ were $B_{L}$ at $25^{\circ} \mathrm{C}$.

\section{TABLE IV}

Effects of chronic nucleus basalis lesion on cortical muscarinic receptors assayed at $4^{\circ} \mathrm{C}$

The nucleus basalis was lesioned unilaterally by stereotaxic injection of $18 \mu \mathrm{g}$ of ibotenic acid. The rats were killed 5 weeks after lesion and the frontoparietal cortex was dissected away. A wedge of the specimen was assayed for choline acetyltransferase activity. The membranes prepared from the samples were assayed for the specific binding of $\left[{ }^{3} \mathrm{H}\right] \mathrm{QNB}$ and carbachol displacement of $\left[{ }^{3} \mathrm{H}\right] \mathrm{QNB}$ with all procedures performed at $4^{\circ} \mathrm{C}$. The results are the means $( \pm \mathrm{SEM})$ of the computergenerated values for the number of preparations indicated in parentheses.

\begin{tabular}{lrr}
\hline & Control (8) & \multicolumn{1}{c}{ Lesion (8) } \\
\hline$B_{H}$ (pmol/mg tissue) & $61 \pm 6$ & $94 \pm 8^{a}$ \\
$B_{L}$ (pmol/mg tissue) & $119 \pm 7$ & $110 \pm 10$ \\
$B_{M}$ (pmol/mg tissue) & $180 \pm 6$ & $204 \pm 15$ \\
$B_{H}$ (\%) & $34 \pm 3$ & $46 \pm 3^{a}$ \\
Choline acetyltransferase & $32 \pm 1$ & $13 \pm 2^{a}$ \\
$\quad$ (nmol/mg protein/hr) & & \\
\hline
\end{tabular}

\footnotetext{
${ }^{a} p<0.025$ versus control.
}

\section{TABLE V}

Effects of nucleus basalis lesion on DFP-induced down-regulation of cortical muscarinic receptors

The nucleus basalis was ablated unilaterally by an electrothermic lesion. Three weeks after lesion, the lesioned rats were treated for 5 days with DFP according to the protocol described under "Materials and Methods." The rats were killed, and the frontoparietal cortex ipsilateral and contralateral to the lesion and from age-matched controls was dissected. Cortical membranes were assayed for the specific binding of $\left[{ }^{3} \mathrm{H}\right] \mathrm{QNB}(1.75 \mathrm{nM})$ at $25^{\circ} \mathrm{C}$. The results are the mean $( \pm$ SEM) of the number of preparations indicated in parentheses.

\begin{tabular}{lcc}
\hline & {$\left[{ }^{3} \mathrm{H}\right] Q N B$ Bound } & $\Delta \%$ \\
\hline & pmol/gm & \\
Control (6) & $231 \pm 8$ & \\
Lesion (11) & $182 \pm 6^{a, b}$ & $-21 \pm 3$ \\
Contralateral (11) & $167 \pm 7^{a}$ & $-28 \pm 3$ \\
\hline
\end{tabular}

${ }^{a} p<0.001$ versus control.

${ }^{b} p<0.05$ versus contralateral by the paired $t$ test.

pathway, the protective effects of the $\mathrm{nBM}$ lesion on the down-regulation of cortical muscarinic receptors associated with chronic treatment with DFP were examined. In these rats, the $\mathrm{nBM}$ lesions caused a $54 \pm 3 \%$ decrease in choline acetyltransferase activity in the ipsilateral frontoparietal cortex and the chronic DFP treatment depressed the activity of cortical acetylcholinesterase by $90 \pm 2 \%$ on the contralateral side. Muscarinic receptor characteristics on the lesioned and contralateral side were compared to those of control. As shown in Table V, the $\mathrm{nBM}$ lesion only partially protected against the reduction in the number of $\left[{ }^{3} \mathrm{H}\right] \mathrm{QNB}$ binding sites; there was a $21 \%$ decrease on the side ipsilateral to the lesion as compared to a $28 \%$ decrease on the side contralateral to the lesion. With the assumption that $K_{H}$ and $K_{L}$ were the same as determined in Table I, the "abbreviated assay" indicated that receptor modulation was restricted to the low affinity agonist sites.

\section{Discussion}

Muscarinic receptors have an uneven distribution in subregions of the cerebral cortex. Analysis of agonist conformational states indicates that this variation reflects primarily differences in the density of high affinity agonist sites, which range over 2 -fold, whereas the low affinity sites remain relatively constant in density. Notably, in the frontoparietal cortex, there is an impressive correlation between the amount of cholinergic innervation derived from the $\mathrm{nBM}$ and the number of high affinity muscarinic receptors. Since acute lesions of the basal globus projection (less than $72 \mathrm{hr}$ ) did not affect the high affinity agonist sites, this correlation between subcortical cholinergic innervation and high affinity agonist density probably reflects a postsynaptic localization of the high affinity sites. Only the low affinity sites exhibited a slight but significant decrease within 3 days of lesion, suggesting a partial presynaptic localization of the low affinity sites. That low affinity sites may serve as autoreceptors is consistent with the dose-response curves for agonist-induced inhibition of acetylcholine release (Szerb, 1978).

Results from our pharmacologic manipulations of rat cortex are in agreement with previous findings in the rat 
hippocampal formation (Ben-Barak and Dudai, 1980a; Gazit et al., 1979) and the corpus striatum (Ehlert et al., 1979). Chronic administration of a muscarinic receptor blocker increased the antagonist binding of muscarinic receptors in the cerebral cortex, whereas chronic administration of an acetylcholinesterase inhibitor resulted in a significant reduction in the concentration of muscarinic receptors. These receptor adaptations occurred relatively rapidly, with maximal alterations achieved within 3 to 5 days of initiation of drug treatment. The displacement studies with carbachol further revealed differential effects of these drug treatments on high affinity and low affinity agonist sites. Chronic administration of DFP resulted in the selective decrease in the number of low affinity sites, whereas both sites, but more so the high affinity sites, increased after chronic treatment with atropine. The study of Ehlert et al. (1979) in the rat striatum also indicated a preferential decline in low affinity agonist sites after chronic treatment with DFP.

The present study demonstrates the differential regulation of high and low affinity states of the muscarinic receptors with chronic alterations in cortical cholinergic input to the receptors. Birdsall and Hulme (1976) speculated that the low affinity site is coupled to a transducer (e.g., ion channel), whereas the high affinity site represents an uncoupled form of the receptor. Recent studies indicate that preincubation of muscarinic receptor preparations with guanyl nucleotides causes the interconversion of agonist high affinity sites to low affinity sites (Sokolovsky et al., 1980; Berrie et al., 1979); these results are consistent with the role of the guanyl nucleotide binding protein in the initiation of receptor-transducer coupling in other receptor systems (Creese et al., 1979; Tsai and Lefkowitz, 1979). That the low affinity agonist site is the "coupled" muscarinic receptor is supported further by dose-response studies of cyclic GMP stimulation in cultured mouse neuroblastoma (El-Fakahany and Richelson, 1980) in which the $\mathrm{EC}_{50}$ for carbachol is approximately $70 \mu \mathrm{M}$, similar to the $K_{D}$ of the low affinity site in cortical membranes. Conceivably then, modulation of muscarinic receptor sensitivity could involve changes in the number of receptors as well as in its coupling to a regulatory unit or transducer (Ehlert et al., 1981; El-Fakahany and Richelson, 1981).

According to this model, the response of the muscarinic receptors to pharmacologic attenuation or potentiation of cholinergic neurotransmission would be an increase or decrease, respectively, in the proportion of the receptors in the coupled state $\left(B_{L}\right)$. Consistent with this hypothesis, DFP-induced desensitization results in a decrease in the number of cortical muscarinic receptors as well as those in the coupled form $\left(B_{L}\right)$. Atropine-induced supersensitivity causes an increase in the total number of receptors, but a striking elevation is found in the percentage of receptors in the high affinity form. At first glance, this would seem at variance with the model. However, the absolute quantity of high affinity receptors increases $590 \mathrm{pmol} / \mathrm{mg}$ of protein, but the low affinity sites also exhibit a substantial increase in absolute number (330 pmol/mg of protein). Thus, an increase in the coupled forms $\left(B_{L}\right)$ does occur with atropine treatment.
Chronic lesion of the major cholinergic pathway innervating the frontoparietal cortex did not alter total muscarinic receptor number in comparison to control. Similarly, ablation of the septohippocampal cholinergic pathway did not cause increases in the muscarinic receptors in the hippocampal formation (Yamamura and Snyder, 1974; Ben-Barak and Dudai, 1980b). When the chronic $\mathrm{nBM}$ lesion was compared to the acute lesion, however, a modest increase in total cortical muscarinic receptors due to an increase in the postsynaptic high affinity sites $\left(B_{H}\right)$ was observed. This response of the high affinity receptors was only one-third of that following treatment with atropine, which we presume to be the maximum upregulation possible and to reflect primarily changes in postsynaptic sites. The lesser than maximal response after chronic denervation suggests that fewer receptors are devoted to receiving the subcortical input than to intrinsic cortical cholinergic systems.

Prior ablation of the septohippocampal cholinergic pathway completely prevented muscarinic receptor down-regulation by DFP treatment in the hippocampus (Ben-Barak et al., 1980b), but nBM lesion provided only limited protection against cortical muscarinic receptor desensitization with chronic DFP treatment. It must be noted, however, that nearly a third of the cholinergic innervation to the frontoparietal cortex is derived from neurons intrinsic to the cortex (Johnston et al., 1981a). Thus, the modest up-regulation of muscarinic receptors following $\mathrm{nBM}$ lesions and the limited protection against DFP-induced down-regulation by this lesion suggests that cholinergic neurons intrinsic to the neocortex either are able to compensate for the loss of the $\mathrm{nBM}$ projection or that the intrinsic neurons play a dominant role in the synaptic modulation of cortical muscarinic receptors. Laminar analysis suggests that both the extrinsic and intrinsic cholinergic systems distribute to all cortical layers (Johnston et al., 1981a).

\section{References}

Ben-Barak, J., and Y. Dudai (1980a) Early septal lesion: Effect on the development of the cholinergic system in rat hippocampus. Brain Res. 185: 323-334.

Ben-Barak, J., and Y. Dudai (1980b) Scopolamine induces an increase in muscarinic receptor level in rat hippocampus. Brain Res. 193: 309-313.

Ben-Barak, Y., H. Gazit, and Y. Dudai (1980) Fornix lesion prevents an organophosphate-induced decrease in muscarinic receptor levels in rat hippocampus. Brain Res. 194: 249-253.

Berrie, C. P., N. J. M. Birdsall, A. S. V. Burgen, and E. C. Hulme (1979) Guanine nucleotides modulate muscarinic receptor binding in the heart. Biochem. Biophys. Res. Commun. 87: 1000-1005.

Birdsall, N. J. M., and E. C. Hulme (1976) Biochemical studies on muscarinic acetylcholine receptors. J. Neurochem. 27: 7-16.

Birdsall, N. J. M., A. S. V. Burgen, and E. C. Hulme (1978) The binding of agonists to brain muscarinic receptors. Mol. Pharmacol. 14: 723-736.

Birdsall, N. J. M., A. S. V. Burgen, and E. C. Hulme (1979) A study of the muscarinic receptor by gel electrophoresis. Br. J. Pharmacol. 66: 337-342.

Birdsall, N. J. M., E. C. Hulme, and A. S. V. Burgen (1980) The character of the muscarinic receptors in different regions of 
the rat brain. Proc. R. Soc. Lond. (Biol.) 207: 1-12.

Bull, G., and B. Oderfeld-Nowak (1971) Standardization of a radiochemical assay of choline acetyltransferase and a study of the activation of the enzyme in rabbit brain. J. Neurochem. 18: 935-947.

Creese, I., T. B. Usdin, and S. H. Snyder (1979) Dopamine receptor binding regulated by guanine nucleotides. Mol. Pharmacol. 16: 69-76.

Ehlert, F. J., N. Kokka, and A. S. Fairhurst (1979) Altered $\left[{ }^{3} \mathrm{H}\right]$-quinuclidinyl benzilate binding in the striatum of rats following chronic cholinesterase inhibition with di-isopropylfluorophosphate. Mol. Pharmacol. 17: 24-30.

Ehlert, F. J., Y. Dumont, W. R. Roeske, and H. I. Yamamura (1980) Muscarinic receptor binding in rat brain using the agonist, $\left[{ }^{3} \mathrm{H}\right]$-cismethyldioxolane. Life Sci. 26: 961-967.

Ehlert, F. J., W. R. Roeske, and H. I. Yamamura (1981) Muscarinic receptor: Regulation by guanine nucleotides, ions and $N$-ethylmaleimide. Fed. Proc. 40: 153-159.

El-Fakahany, E., and E. Richelson (1980) Temperature dependence of muscarinic acetylcholine receptor activation, desensitization and resensitization. J. Neurochem. 34: 12881295.

El-Fakahany, E., and E. Richelson (1981) Effects of lanthanides on muscarinic acetylcholine receptor function. Mol. Pharmacol. 19: 282-290.

Fletcher, J. E., and R. I. Shrager (1973) A User's Guide to Least Squares Model Fitting, Technical Report No. 1, United States Department of Health, Education, and Welfare, Public Health Service, National Institutes of Health, Bethesda, MD.

Gazit, H., I. Silman, and Y. Dudai (1979) Administration of an organophosphate causes a decrease in muscarinic receptor levels in rat brain. Brain Res. 174: 351-356.

Hulme, E. C., N. J. M. Birdsall, A. S. V. Burgen, and P. Mehta (1978) The binding of antagonists to brain muscarinic recep- tors. Mol. Pharmacol. 14: 737-750.

Johnston, M. V., and J. T. Coyle (1980) Ontogeny of neurochemical markers for noradrenergic, GABAergic and cholinergic neurons in neocortex lesioned with methylazoxymethanol acetate. J. Neurochem. 34: 1429-1441.

Johnston, M. V., M. McKinney, and J. T. Coyle (1979) Evidence for a cholinergic projection to neocortex from neurons in basal forebrain. Proc. Natl. Acad. Sci. U. S. A. 76: 5392-5396.

Johnston, M. V., A. C. Young, and J. T. Coyle (1981a) Laminar distribution of cholinergic innervation in rat neocortex: Lesions of extrinsic and intrinsic components. J. Neurosci. Res., in press.

Johnston, M. V., M. McKinney, and J. T. Coyle (1981b) Neocortical cholinergic innervation: A description of extrinsic and intrinsic components in the rat. Exp. Brain Res. 45: 159-172.

Simon, R. G., and W. L. Klein (1979) Cholinergic activity regulates muscarinic receptors in nervous system cultures. Proc. Natl. Acad. Sci. U. S. A. 76: 4141-4145.

Sokolovsky, M., D. Gurwitz, and R. Galeon (1980) Muscarinic receptor binding in mouse brain: Regulation by guanine nucleotides. Biochem. Biophys. Res. Commun. 94: 487-492.

Szerb, J. C. (1978) The characterization of presynaptic muscarinic receptors in central cholinergic neurons. In Cholinergic Mechanisms and Psychopharmacology, D. J. Jenden, ed., pp. 49-60, Plenum Press, New York.

Tasi, B. S., and R. J. Lefkowtiz (1979) Agonist-specific effects of guanine nucleotides on alpha-adrenergic receptors in human platelets. Mol. Pharmacol. 16: 61-68.

Wilson, S. H., B. K. Schrier, J. L. Farber, E. J. Thompson, R. N. Rosenberg, A. J. Blume, and M. J. Nirenberg (1972) Markers for gene expression in cultured cells from the nervous system. J. Biol. Chem. 147: 3159-3169.

Yamamura, H. I., and S. H. Snyder (1974) Muscarinic cholinergic binding in rat brain. Proc. Natl. Acad. Sci. U. S. A. 71: 1725-1729. 